\title{
Protected areas, tourism economy and employment generation: A case study from India
}

\author{
Shweta Sharma*, Shamli Sood, Pradeep Chaudhry \\ Indian Institute of Forest Management, Nehru Nagar, Bhopal, India - 462003 \\ *e-mail: ssharma20@iifm.ac.in
}

Received: 24 September 2019 / Accepted: 23 November 2019

\begin{abstract}
Wildlife tourism in the form of Tiger Tourism dominates in India as the country is home to more than half of the world's tiger population. The first tiger reserve was established in India in 1973.At present, there are 50 tiger reserves in the country, which are administered by the National Tiger Conservation Authority (NTCA) at the central level and state forest \& wildlife departments at the field level. The present case study concerns the assessment of tourism economy and employment generation in one of the prominent tiger reserves in India, i.e. the Satpura Tiger Reserve of the Madhya Pradesh state. Based on the primary and secondary data, it has been estimated that the expenditure incurred by tourists in the Satpura Tiger Reserve between 2017 and 2018 amounted to INR 1,110 million (equivalent to USD 15,416,666; 1 USD = 72 INR). At the same time, around 127,187 man-days were generated for the nearby local community from the tourism establishments.
\end{abstract}

Key words: protected area, tiger reserve, livelihood generation, community development, Pachmarhi Biosphere Reserve.

\section{Introduction}

Protected areas (PAs) cover around $12 \%$ of the world's geographical area (Chape et al, 2005). Though recorded forest area of India is about $23.34 \%$ (State of Forest Report, 2017) but the country's protected area network covers less than $5 \%$ of the country's area. India's 771 PAs are small (average size $<300 \mathrm{~km}^{2}$ ), highly fragmented, and surrounded by high densities of people (Rodgers et al., 2003). Forest managers are under tremendous pressure in saving these areas from commercial interests (mining, roads, transmission lines mainly) and biotic pressures (fuelwood, fodder, and non-timber forest products collection, grazing, and hunting). Nature-based or eco-tourism adds another dimension to these existing challenges (Karanth \& Defries, 2010).

India is home for about sixty percent of the world's wild tiger population (Jhala et al, 2015). Madhya Pradesh state of India is known as tiger state of India because of the maximum tiger presence while comparing with other states. The state is bestowed with luxuriant forest which covers more than $30 \%$ of its geographical area. There are six tiger reserves, many national parks and sanctuaries, inhabiting rich biodiversity along with picturesque landscape and water bodies in the state. Studies related to the assessment of tourism economy and jobs creation due to protected areas are very rare in India, hence Satpura Tiger Reserve (STR) of the state was selected for conducting this kind of study (Figs 1-4). The study was sponsored by Madhya Pradesh Tiger Foundation Society (MPTFS), a non-profit organization of the state and was carried out during the period April 2019 to June 2019 by the first author. The aim of the study was to assess tourists' expenditurein the tiger reserve and also the assessment of jobs/livelihood generated by this tiger reserve, thereby its contribution to the local economy. 


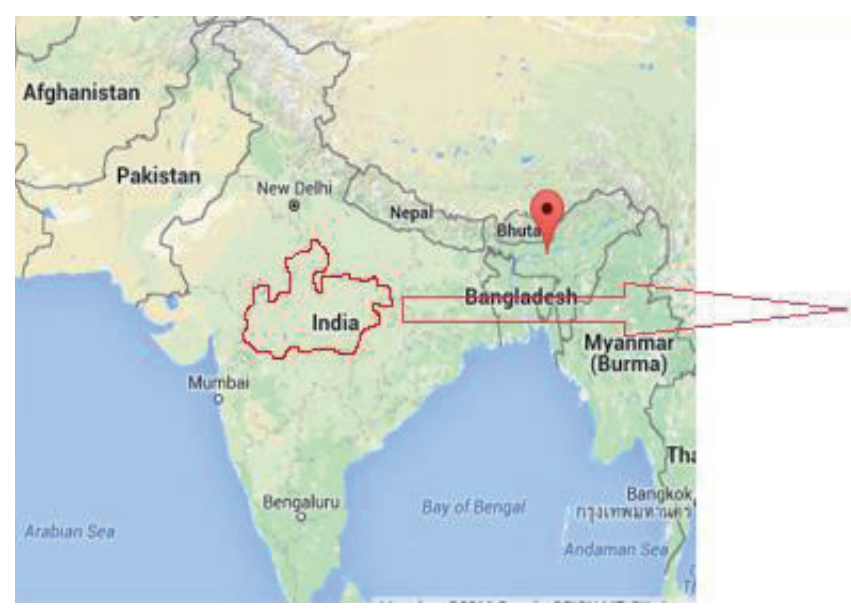

Figure 1. Map of India

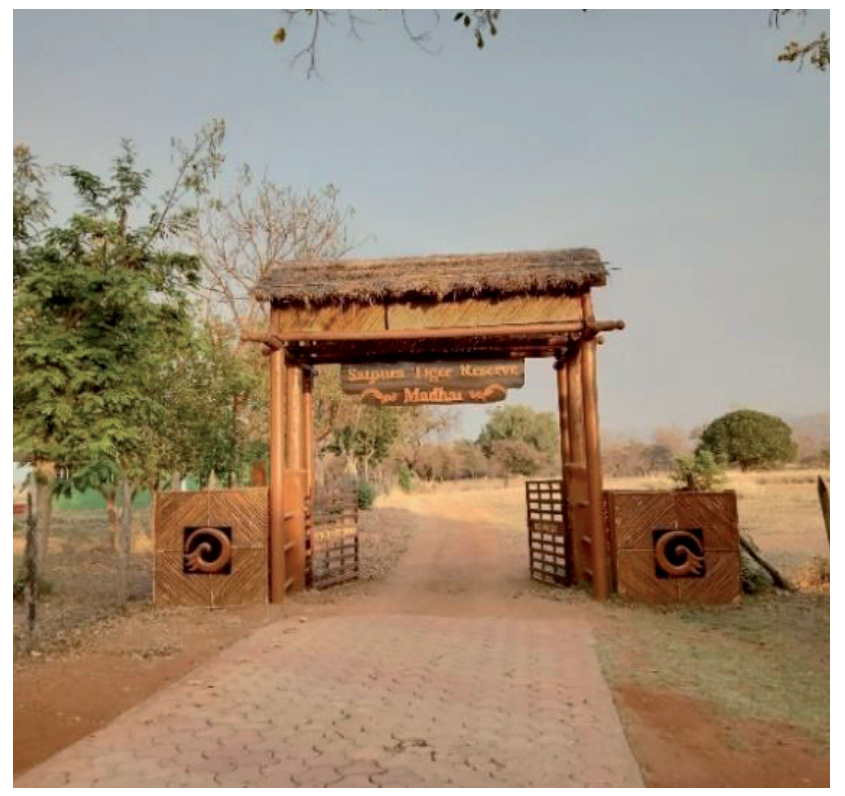

Figure 3. Entry gate of Satpura National Park

\section{Study Area}

Satpura Tiger Reserve (STR) is located in Hoshangabad district of Madhya Pradesh. Its name is derived from Sanskrit word Satpura which means seven mountains. It encircles three protected areas namely Satpura National Park $\left(528.73 \mathrm{~km}^{2}\right)$, Bori Sanctuary $\left(485.71 \mathrm{~km}^{2}\right)$, and Pachmarhi Sanctuary $\left(491.63 \mathrm{~km}^{2}\right)$ which forms the Critical Tiger Habitat (CTH), and a peripheral buffer area of $794.04 \mathrm{~km}^{2}$. National Tiger Conservation Authority guidelines allow tourism only in $20 \%\left(301.214 \mathrm{~km}^{2}\right)$ of the CTH. Due to the combination of various climatic and edaphic factors at

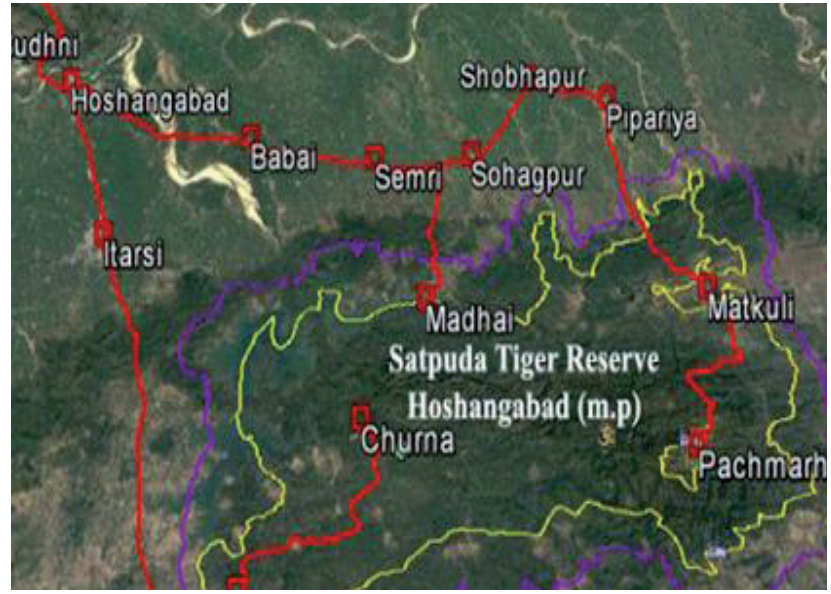

Figure 2. Map of STR

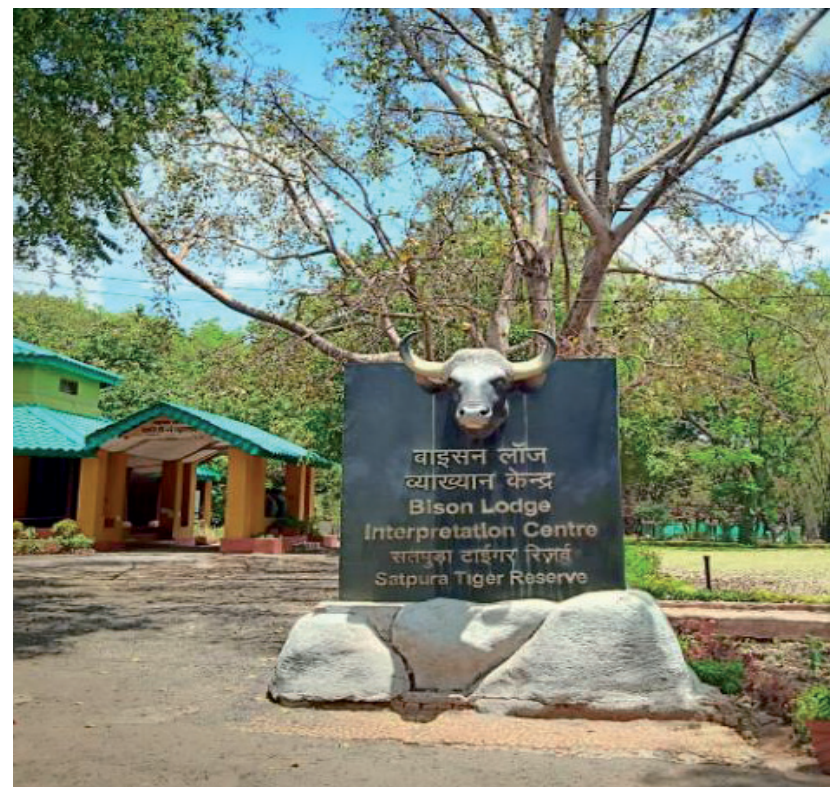

Figure 4. Bison Lodge interpretation center at Pachmarhi

different altitudinal levels the reserve is the home to almost 62 big trees species, 30 small tree species, 58 shrub species, 32 climber species, and nearly 64 grass species. Many rare and endemic species of medicinal plants and herbs are also found in this area. The reserve also provides home to around 52 species of mammals and 31 species of reptiles. Moreover, STR is very rich in avian diversity as more than 300 species of birds are found in this tiger reserve (Satpura Tiger Reserve). 


\subsection{Tourism Zones in STR}

Madhai

This place falls under the core area of STR. The visitors have to cross the Denwa river to reach this area. The ecotourism activities offered in this area include vehicle safaris, elephant safaris, boat riding, and canoeing. A vehicle entering through this gate (Fig. 3) can choose any path among Keriya, Jhinjhini Mahal, Lagda, and Chutkidev. Only 38 vehicles per day are allowed to enter the gate, including morning and evening Safaris.

\section{Pachmarhi}

Pachmarhi (a hill station) was discovered by Captain J. Forsyth of the British Army in 1862 and is designated as Queen of Satpura. It is under the administration of Cantonment Board (CB), Indian Army. The tourism at Pachmarhi is based mainly on sight-seeing and is different from other tourism zones of STR, where predominantly tiger tourism prevails. Endowed with a large number of waterfalls, narrow gorges, caves, mountain peaks, and ancient temples, Pachmarhi is a naturalists' paradise. There are more than 30 forest points in this area. Some of these points can only be accessed after getting entry ticket from Bison lodge (Fig. 4). which was the first building built at Pachmarhi by Captain J. Forsyth, and is now a wildlife and cultural interpretation centre. Also, Pachmarhi is significant from the archaeological viewpoint as many of the rock paintings engraved on the caves are believed to be about 1000 years old. In May 2009, Pachmarhi was added to include in the list of Biosphere Reserves by the UNESCO.

\section{Churna}

This area is situated in the deep core forest. There are two entrances to this area; one is from Madhai, and the other is from Bhimkund barrier. Visitors can explore this area in their private vehicles.

\section{Bagra Buffer}

This buffer zone is located nearby Madhai. The visitors can explore this area with their vehicles or any other private vehicle owned by locals or resort owners. Only 56 vehicles can enter this buffer area per day either through Paraspani gate or through Jamanidev gate.

\section{Materials and methods}

Based on the understanding of existing literature, structured questionnaires were prepared for three stakeholders: tourists, hotels, and local professionals/businessmen (Table 1). These questionnaires were modified later in the field to incorporate some of the points that were left out while preparing the questionnaires.

Following secondary data was collected for the year 2017-18, from the main office of MPTFS to meet the objectives of the study:

- Number of domestic and foreign tourists visiting the tourism zones of STR.

- Number of vehicles entering the tourism zones of STR.

- Fund allocated to STR from the central and state government.

- Revenue generated from the park in the form of entry fee, rest house fees etc.

- Financial statement (Vikas Nidhi) which is also known as the Park Development Fund (PDF).

The secondary data was analyzed to determine the net economic value of tourism in the Satpura Tiger Reserve. 80 tourists and 10 hotels were surveyed in Madhai, including samples of adjoining areas (Churna and Bagra Buffer area). The tourists were surveyed at the entry gate as well as in the hotels/resorts. 300 tourists and 40 hotels

\section{Formulae Sheet}

Tourist expenditure $=($ Stay + Food + Travel + Souvenir + Other $)$ expenditure

Total number of entries $=\sum$ (Number of visitors in a group $*$ Total Safari taken per group)

Average expenditure per entry $=$ Total expenditure of all entries/ Total number of entries

Expenditure incurred by entries in single strata $=$ Average expenditure per entry $*$ (Number of entries of given strata in the sample / Total number of entries in the sample) * Total entries in a particular year

Total expenditure incurred by tourist $=$ Expenditure incurred by tourists in all strata + Total entry fees in a particular year + Total Gypsy fees + Total Guide fees

Leakage $=$ Total expenditure incurred by tourists including entry and Gypsy fees- Total amount retained by service providers involved in tourism 


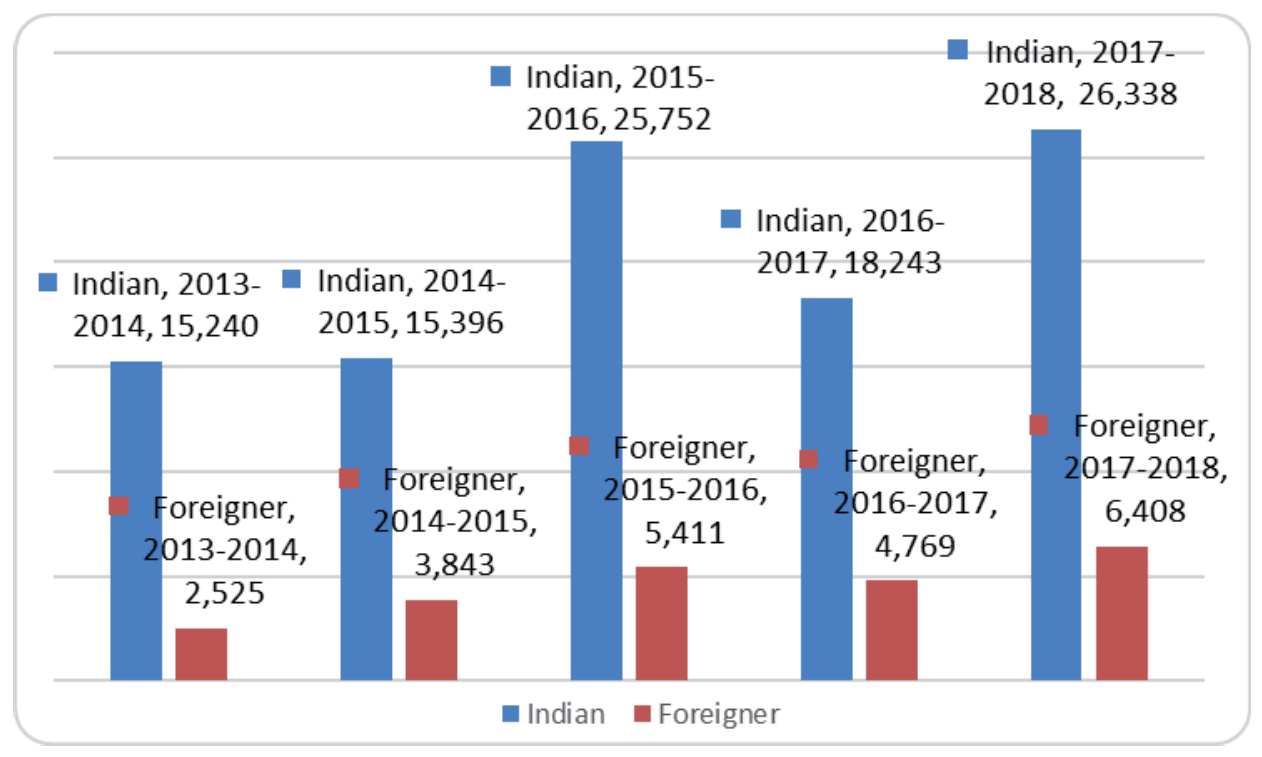

Figure 5. Number of Indian and foreign entries in Madhai, Churna, and Bagra Buffer in 5 years

and 30 local professionals/businessmen were surveyed/ interviewed at Pachmarhi to find out the amount that is getting inflexed into the local economy. In nutshell thus, overall 380 tourists, 50 hotels, and 30 local businessmen were surveyed. Convenience sampling, a non-probabilistic sampling technique where tourists are selected because of their convenient accessibility as well as proximity to the researcher, was used. Using this sampling technique data was collected from tourists, hotels, and local professionals/businessmen. The tourists were divided into three strata named as budget, premium, and luxury depending on their accommodation expenses. The expenditure incurred by each stratum was calculated separately using formulae/ equation as given in the box.

Like tourists, hotels were also divided into strata named as budget, premium, and luxury, depending on their average tariff/night. Afterward, average annual occupancy and tariff/night were calculated for each segment ${ }^{1}$. Finally using this average value, total income was calculated for each strata of hotels. This annual turnover was calculated for 273 days in Madhai as the park remains open for about 9 months only during the year and for 365 days in Pachmarhi as it remains open for 12 months at Pachmarhi. The average earning of local shops and restaurants was also calculated from the sample size. The annual income was calculated by multiplying this value with the total number of shops.

\footnotetext{
1 The terms "strata" and "segment" are used interchangeably to represent category of hotels
}

\section{Results}

Madhai

Tourist inflow

Figure 5 shows the trend of Indian and Foreign tourists in Madhai, Churna, and buffer area for the period 2013-14 to 2017-18. It is observed that there has been a continuous increase in the number of tourists entering the park from 2013-14 till 2017-18 except for the year 2016-17, and the main reason behind the decline of tourist in 2016-17 was demonetization that took place in India from November, 8th 2016 night. During the demonetization process, INR 500/- and INR 1000/- were discontinued by Central Government to curb the black money in the economy of the country.

\section{Primary Data Analysis}

80 tourist units ${ }^{2}$ were surveyed at Madhai. Based on the unit/group size, the total visitors were 310 . Out of these, 11 tourist units came from Pachmarhi, so their expenditure was included in Pachmarhi, and also there were 3 day-visitors who were excluded from the sample because of their less representation in the sample. But, there were a day-visitors in actual population, and excluding them may overestimate the revenue. Therefore, in order to counterbalance

\footnotetext{
${ }^{2}$ A tourist unit refer to family or group of people from which only one member was surveyed.
} 


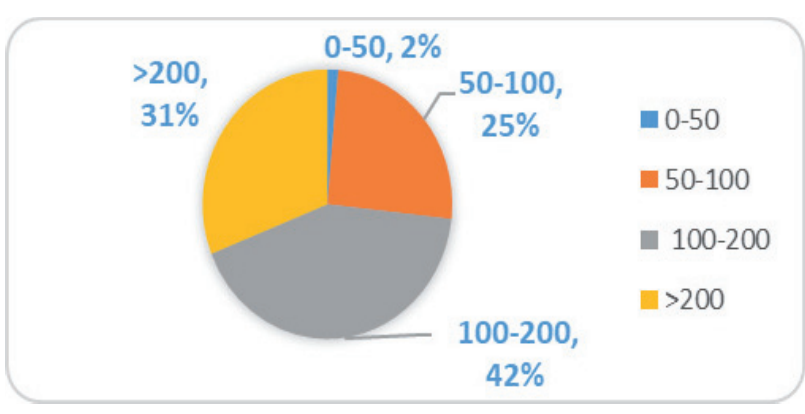

Figure 6. Percentage breakup of tourist units according to their monthly income range (expressed in INR 1000)

this effect, high-end professionals like photographers, researchers, etc. were also excluded from the sample.

Figure 6 describes the income range of respondents surveyed in the field. Number of respondents with income less than INR 50,000 were comparatively lesser than other groups, and the prime reason for that was higher entry and Safari fees as intimated by few respondents. The expenditure incurred by tourists was calculated differently for the foreign and Indian tourists using the formulae sheet.
Following assumptions were taken for carrying out the analysis:

- Foreigner's package is inclusive of safari charges and entry fees.

- The strata of tourists in the sample taken in the year 2019 is an actual representation of tourists that entered STR in 2017-18.

- The tourists who visited the tiger reserve have taken a safari.

- The employee details of un-surveyed hotels were assumed in the ratio estimated from surveyed ones.

- One day-visitors were taken out of the sample because of their less representation in the sample.

- For tourists who didn't know their hotel price, it has been estimated from their hotel plans.

- No. of Man-days generated were calculated considering INR 200 as daily wage.

Foreign tourists' analysis

Nine foreigner units were surveyed in Madhai, and all of these units encountered in the field fall under the luxury category. Based on the group or family size of surveyed foreign tourist units, the total number of foreign visitors were 26. The average expenditure per entry in case of a foreigner was INR 14,689.34. This value was extrapolated to

Table 1. Objectives for surveying different stakeholders

\begin{tabular}{|c|c|}
\hline Questionnaires & Objectives \\
\hline Tourists & $\begin{array}{l}\text { - Expenditure details pertaining to food, stay and } \\
\text { travel } \\
\text { - Feedback of place }\end{array}$ \\
\hline Hotels and Resorts & $\begin{array}{l}\text { - Occupancy details } \\
\text { - Number of local employees } \\
\text { - Average tariff/night }\end{array}$ \\
\hline Local Professional/Businessman & $\begin{array}{l}\text { - Type of business } \\
\text { - Monthly income }\end{array}$ \\
\hline
\end{tabular}

Table 2. Percentage of budget, premium and luxury Indian tourist in a given sample size at Madhai

\begin{tabular}{|c|c|c|}
\hline Category & Sample units & Percent \\
\hline Budget & 20 & $35.09 \%$ \\
\hline Premium & 25 & $43.86 \%$ \\
\hline Luxury & 12 & $21.05 \%$ \\
\hline Total & 57 & $100 \%$ \\
\hline
\end{tabular}




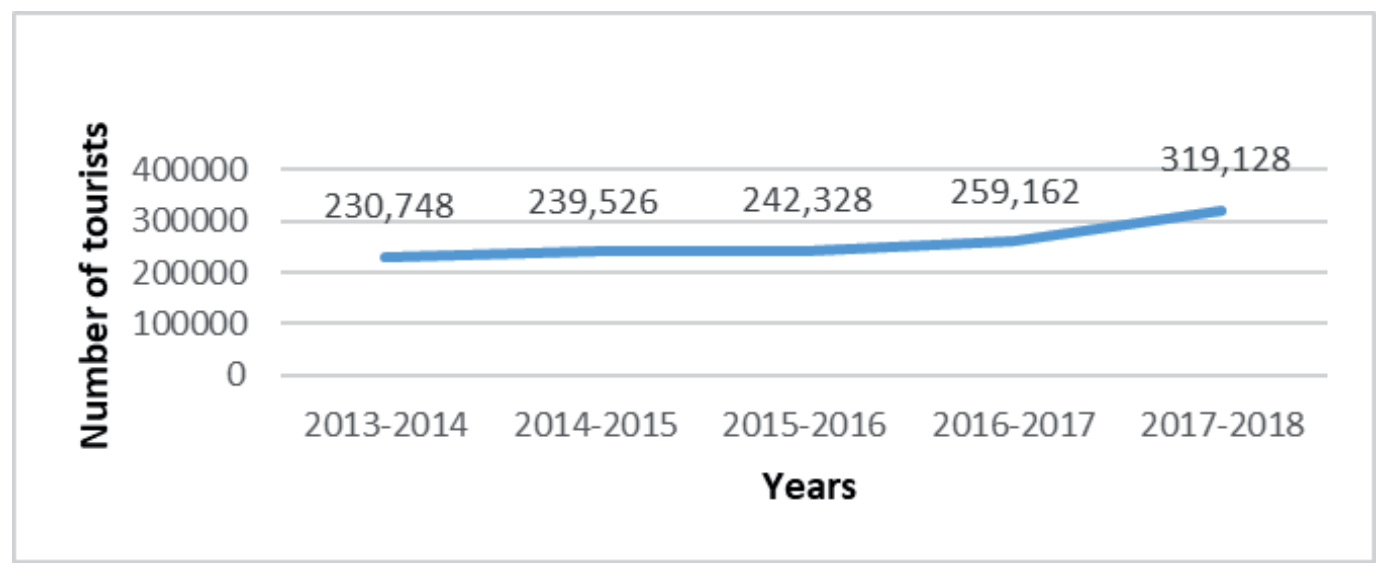

Figure 7. Number of tourists that entered forest points of Pachmarhi in 5 years

the total number of foreigners that entered Madhai, Churna and Bagra buffer in the year 2017-18. The total expenditure incurred by foreigners during the year 2017-18 was estimated to be INR 9,4,129,282.45 (USD 1,324,193.15).

\section{Indian tourists' analysis Budget}

The tourists who stayed in the hotels ranging below INR 5,000 / night tariff were considered as budget tourists. Out of 57 Indians surveyed, 20 fall under budget category. Based on the group size, 120 visitors were considered as budget tourists. The average expenditure incurred by budget Indian per entry was calculated to be INR 2,112.21. After extrapolating this value to the previous year, the total expenditure incurred by budget travelers was estimated to be INR 1,9,843,027 (USD 275,597.60).

\section{Premium}

The tourists who stayed in the hotels ranging from INR $5,000-11,999 /$ night tariff were considered as premium tourists. Out of 57 Indians surveyed, 25 sampled units fall under premium category. Based on the group size, 152 visitors were considered as budget tourists. The average expenditure incurred by premium Indian tourists per entry was INR 3,421.29, and after extrapolating this amount to the previous year, the total expenditure by premium category tourists was estimated to be INR 4,3,046,245.64 (USD 597,864.52).

\section{Luxury}

The tourists staying in the hotels ranging above INR $11,999 /$ night tariff were considered as luxury tourists. Out of total Indian surveyed, 12 units were of luxury category. Based on the group size, 38 visitors were considered as luxury tourists. The average amount spent per entry by a luxury tourist was INR 9,566.46. Therefore, after extrapolating this average to the previous year, the total expenditure incurred by luxury tourists was estimated to be INR 4,1726,102 (USD 579,529.19).

Therefore, the total expenditure incurred by Indian tourists turned out to be INR 104,615,374.80 (USD $1,452,991.32)$. Adding this to the expenditure of foreigners, the total expenditure incurred by tourists in year 2017 18 was INR 198,744,657.20 (USD 2,760,342.46). After including the gypsy, guide and entry fees, the total revenue generated from tourism in Madhai, Churna and adjoining buffer area during the year 2017-18 was estimated to be INR 221.40 million (USD 3,075,000).

\section{Verification}

A portion of the revenue generated from Madhai, Churna and Bagra buffer was retained by the people involved in tourism in these areas like drivers, guides, and hotels. Since there is no other option of entertainment, the majority of revenue generated from the above mentioned areas was retained within these areas.

Of the 10 wildlife lodges surveyed, 3 were luxury, 3 were premium and remaining 4 were from budget segment. The estimated annual turnover of 12 wildlife lodges, and associated services in Madhai was INR 164,657,902 or USD 2,286,915.30. (Table 3). These lodges generate jobs for residents of Madhai as well as outsiders, the details of which are given below in Table 4 .

Of all these employees, the senior-level and middlelevel staff were outsiders junior-level staff was from nearby villages.

The sum total of annual income of different service providers in Madhai was INR.192,697,763.5 or USD 2,676,357.83 (Table 5). Therefore, the leakage in Madhai 
was estimated to be INR 28,340,564.7 (USD 393,618.95) (Formulae sheet). Some of this leakage was the amount spent by tourists in reaching the tourism zones via flight, train or road transport.

\section{Pachmarhi \\ Tourist inflow}

Figure 7 shows the trend of tourists in Pachmarhi starting from 2013-14 to 2017-18. Unlike Madhai, the effect of demonetization was not seen in Pachmarhi, and the tourism in Pachmarhi grew at a rate of $38.30 \%$ in $2017-18$ as compared to 2013-14.

\section{Primary Data Analysis}

A total of 300 tourist units were surveyed in Pachmarhi. Out of these, 3 were one day-visitors which were excluded from the sample because of less representation in the sample size. Also, 5 other units were excluded from sample size because these people came to Pachmarhi for other reasons like to attend the marriage.

Though the high-income range people were comparatively less in numbers, the money spent by these people creates a huge difference (Fig. 8).

Out of 300 tourist units surveyed, only 3 were foreigners, and the remaining 297 were Indians. So, due to less representation of foreigners in sample size, the analysis of Indians and foreigners in Pachmarhi was done collectively.

\section{Budget}

As described in the analysis of Madhai, the tourists that stayed in the hotel ranging below INR 5,000/ night tariff were considered as budget tourists. The average expenditure per entry by budget tourists in Pachmarhi was estimated to be INR 2,143.47. After extrapolating this to previous year population, the total expenditure incurred by budget travelers turned out to be INR $615,607,446.8$ (USD $8,550,103.43)$.

\section{Premium}

The premium tourists are the ones who stayed in the hotel ranging from INR 5,000-11,999. The average expenditure incurred per entry by premium segment was estimated to be INR 5,069,995,475. After extrapolating this to the year 2017-18, the expenditure incurred by premium tourist turned out to be INR 161,870,996.4 (USD 2,248,208.30).

Therefore, after adding the entry fees and safari charges paid by tourists in the year 2017-18, the total expenditure incurred by tourists in Pachmarhi in the year 2017-18 was estimated to be INR 889 million (USD 12,347,222).

\section{Verification \\ Hotel and Resorts}

Out of 40 hotels and resorts surveyed in Pachmarhi, only four were of the premium category, while the remaining 36 belonged to the budget category.

Table 3. Annual turnover of hotel/resorts/lodges at Madhai

\begin{tabular}{|c|c|c|c|c|c|}
\hline Segment & $\begin{array}{c}\text { Average occupancy } \\
(\%)\end{array}$ & No. of hotels & $\begin{array}{c}\text { No. } \\
\text { of rooms }\end{array}$ & $\begin{array}{c}\text { Average tariff } \\
\text { (in INR) }\end{array}$ & $\begin{array}{c}\text { Annual income for 273 days } \\
\text { (in INR) }\end{array}$ \\
\hline Budget & 45 & 5 & 51 & 3,250 & $20,362,387.5$ \\
\hline Premium & 49.67 & 4 & 45 & 8,100 & $58,710,015$ \\
\hline Luxury & 60 & 3 & 33 & 15,833 & $85,585,500$ \\
\hline Total & & & & & $164,657,902.5$ \\
\hline
\end{tabular}

Table 4. Number of employees in different strata of hotels

\begin{tabular}{|c|c|c|}
\hline Segment & Total employees & Locals \\
\hline Budget & 23 & 20 \\
\hline Premium & 66 & 52 \\
\hline Luxury & 78 & 57 \\
\hline Total & 167 & 129 \\
\hline
\end{tabular}




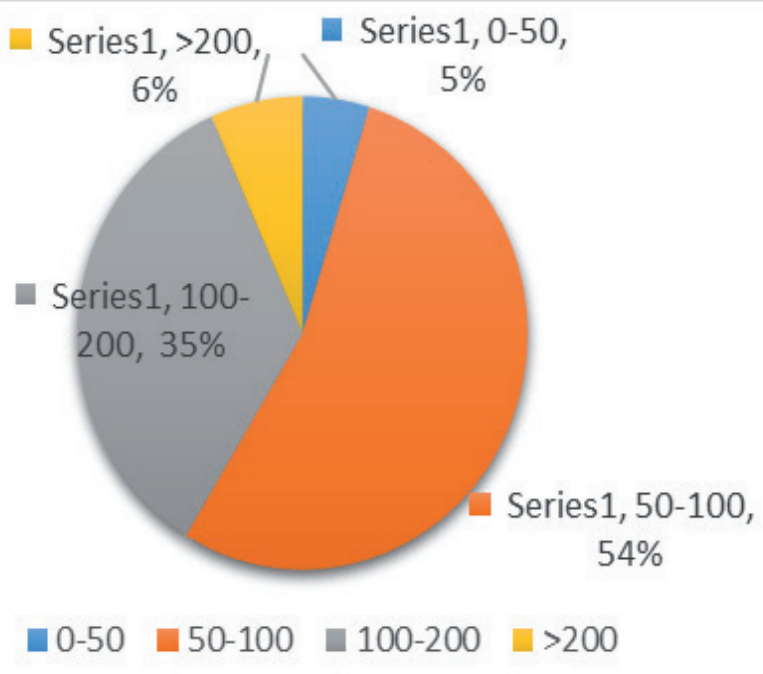

Figure 8. Percentage breakup of tourist units according to their monthly income range (expressed in INR 1000)

Table 5. Annual income of different service providers in Madhai

\begin{tabular}{|c|c|}
\hline Direct Service Providers & Annual Income( in INR) \\
\hline Guides & $1,931,760$ \\
\hline Drivers and Gypsy owners & $13,446,000$ \\
\hline Hotels & $164,657,902.5$ \\
\hline Entry Fees ( MP Govt.) & $12,662,101$ \\
\hline Total & $192,697,763.5$ \\
\hline
\end{tabular}

Table 6. Annual turnover of hotel/resorts/lodges at Pachmarhi

\begin{tabular}{|c|c|c|c|c|c|}
\hline Category(Strata) & $\begin{array}{c}\text { Average } \\
\text { occupancy }(\%)\end{array}$ & No. of hotels & $\begin{array}{l}\text { No. } \\
\text { of rooms }\end{array}$ & Average tariff & $\begin{array}{c}\text { Annual income for } 365 \\
\text { days (in INR) }\end{array}$ \\
\hline Budget & 52.97 & 61 & 748 & $2,010.03$ & $290,698,567.70$ \\
\hline Premium & 66.75 & 4 & 94 & $6,499.50$ & $148,851,061.50$ \\
\hline Total & & & & & $439,549,629.20$ \\
\hline
\end{tabular}


The annual turnover of hotels and resorts in Pachmarhi was estimated to be INR 439,549,629.20 (USD 6,104,856) (Table 6). Like in Madhai these resorts and hotels also generate jobs, the rough estimate of which is given in Table 7.

About one third of the total employees were locals and the remaining were from nearby cities (Table 7).

\section{Local Businessmen and Professionals}

30 local Businessmen and Professionals were surveyed in Pachmarhi. The average annual turnover for the sample size was estimated, and it turned to be around INR 602,748.72. Since the total number of registered shops in Pachmarhi was noticed to be 180 . Therefore, the annual turnover of shops was estimated to be INR 108,494,770.3 (USD 1,506,871.80).

Therefore, INR 799,907,320.9 was retained by the service providers in Pachmarhi (Table 8), and the remaining INR 89,276,367.1 was the leakage (Formulae sheet).

\section{Combined Analysis}

The total expenditure incurred by tourists in Satpura Tiger Reserve in 2017-18 (combining tourist expenditure of Madhai and Pachmarhi) was estimated to be INR 1,110 million (equivalent to USD $15,416,666$ ). Considering the multiplier effect (Filion et al.,1994), the net revenue generated from Tourism in STR was estimated to be INR 2,220 million (USD 30,833,332). The income of people from tourist establishments was observed to be $89.40 \%$ and remaining $10.60 \%$ was found to be leakage from the area.

At the same time around INR 25,437,500 (USD $353,298.61$ ) was allocated by state and central government for the construction and repair of buildings, pipelines, tanks, etc., in STR. Therefore, from a conservative estimate around 127,187 man-days were generated for local community, considering INR 200 as a daily wage.

\section{Biases}

There were biases in the study, some of which were recognized while others could not be recognized. One of the biggest bias in this study was seasonal bias as the study was conducted in a period when less number of tourists visit the place. Also, different seasons attract different regional tourists e.g., Pachmarhi is dominated by tourists from Gujarat during Diwali and tourists from Bengal during Dussehra festival, which might fluctuate the results because of their

Table 7. Number of employees in different strata of hotels

\begin{tabular}{|c|c|c|}
\hline Category & Total employees & Locals \\
\hline Budget & 450 & 153 \\
\hline Premium & 128 & 41 \\
\hline Total & 578 & 194 \\
\hline
\end{tabular}

Table 8. Annual income of different service providers in Pachmarhi

\begin{tabular}{|c|c|}
\hline Direct Service Providers & Annual Turnover ( in INR) \\
\hline Hotels & $439,549,629.2$ \\
\hline Drivers and Gypsy owners & $96,791,096$ \\
\hline Guides & $9,887,060$ \\
\hline Local Businessmen \& Professionals & $223,756,273.7$ \\
\hline Entry Fees & $29,923,262$ \\
\hline Total & $799,907,320.9$ \\
\hline
\end{tabular}


increased travelling cost, which could not be covered in this study. Also, there were some personal biases like if some tourists were busy enjoying among their families, then those tourists were not surveyed to cause them least disturbance. Therefore, our estimate of INR 1,110 million is a conservative one.

\section{Discussion}

Protected areas are under increasing pressure to provide economic justification for their existence, particularly in developing countries like India where demand for land, population density of humans, livestock and forest based natural resources is very high. On one hand, nature-based tourism is increasing due to increased earnings of middle class society, and eco-tourism offers a mechanism to generate substantial benefits from protected areas for both governments on one hand and local communities on the other, and is increasingly promoted as a sustainable use of protected areas (Goodwin, 2010). The potential role of tourism in contributing towards the costs of conservation and providing economic opportunities for communities living adjacent to natural heritage has long been recognized (Goodwin, 2010). It is also true that much attention has been paid to the research conducted in environmental/biodiversity conservation effects whereas very less literature is available on social and economic impacts of protected areas on nearby community (Fortin \& Gagnon, 1999).

Protected areas are expected to directly contribute to national development and poverty reduction (NaughtonTreves et al., 2005). We are not aware of any study related to development of tourism economy and livelihood generation by Satpura Tiger Reserve to local communities. However, a study in five protected areas of nearby Maharashtra state of India is available, where annual agricultural income of around 815 households in non-tourism villages situated away from the five PAs was estimated during the study period. When the annual tourism income of tourism villages was compared with the annual agricultural income, it was found that with half of the effort, and in lesser time, villagers earn a fairly good amount of income from tourism activities, while also earning from agriculture (Roy et al., 2018). Therefore, according to authors, local livelihood or employment opportunities (a kind of annual flow benefit) from these PAs were quite substantial in magnitude in addition to other intangible flow benefits like carbon sequestration, pollination etc.

According to a study done in Ranthambhore Tiger Reserve in year 2018, more than $50 \%$ of revenue generated from tourism establishments is going to local communities (Chundawat et al., 2018). This finding is in contrast to our study which states that more than $50 \%$ of revenue generated from tourism in STR is retained by hotels, resorts, and lodges located in the vicinity of tourism zones. So, a major portion of the revenue is grabbed by the hotel owners and staff employed at top level, most of which were outsiders This prevents local people from deriving substantial benefits from tourism activities, often marginalizing them due to minimal financial benefits (Spiteri \& Nepal, 2008).

However, the tiger tourism was started with the prime motive of providing livelihood to nearby villagers and lifting their status so as to gain their support in managing the Reserve. But this objective has somewhere disappeared and the local residents are only getting meagre benefits from these tourist establishments. Though there is an increase in the social and economic status of villagers living in the vicinity of STR, as compared to their previous situation there is still more that can be done by doing their capacity building and raising environmental awareness (Walpole et al., 2011).

\section{Conclusion}

The contribution of STR to the local economy can be divided in two classes namely, wildlife tourism at (predominantly at Madhai) and sight-seeing (predominantly at Pachmarhi). The former class contributes only $19.90 \%$ to the local economy whereas the latter's contribution is around $80.10 \%$. The reason behind less footfall of tourists in Madhai is because of more orientation of domestic travelers towards sight-seeing. At the same time, wild life tourism is considered to be more expensive, and wildlife areas are visited by wildlife enthusiasts only. However, there is a significant increase of tourists in Madhai as compared to previous years, and this number can be further increased by doing capacity building of these tourism zones via indulging tourists in non-financial activities like bird-survey and introducing facilities like home stays. These initiatives would not only raise the economic value of the area but shall also help in increasing livelihood for local communities.

However, in this era of sustainable development, the focus should not only be in reaping the maximum benefits out of these wilderness areas, but also on preserving the areas to the best extent possible. This can be done by improving waste management plans and following the principle of 3R's (Reduce, Reuse, Recycle) in every possible way. All these add-ons will enhance the beauty of these areas resulting in increasing footfall of tourists in the region.

\section{Acknowledgements}

We express our sincere thanks and gratitude to Dr. U Prakasham, Chief Wildlife Warden (CWLW), Prin- 
cipal Chief Conservator of Forests (Wildlife) \& Secretary, MPTFS; Mr. Rajnish K. Singh, Deputy Conservator of Forests, MPTFS for providing an opportunity to conduct this study. We would also like to thank Mr. S.K. Singh, Field Director (FD), Satpura Tiger Reserve and MP Forest Department, and staff of Satpura Tiger Reserve for logistic support extended to us during the field study.

\section{References}

Chape S., Harrison J., Spalding M. \& Lysenko I., 2005, Measuring the extent and effectiveness of protected areas as an indicator for meeting global biodiversity targets. Philosphical transactions of Royal Society B: Biological Sciences 360(1454): 443-455.

Chundawat D.R., Raju V.U. \& Rajora H., 2018, The value of Wildlife Tourism around Ranthambhore Tiger Reserve in Rajasthan for Wildlife Conservation and Local Communities. TOFTigers, New Delhi, India.

Filion F.L., Foley J.P. \& Jacquemot A.J., 1994, The economics of global tourism, [in:] M. Munasinghe, J. McNeely (eds), Protected Area Economics and Policy: Linking Conservation and Sustainable Development. World Bank, Washington, D.C., USA: 235-252.

Fortin M.-J. \& Gagnon C., 1999, An assessment of social impacts of national parks on communities in Quebec. Environmental Conservation 26(3): 200-211.

Goodwin H., 2010, Local Community Involvement in Tourism around National Parks: Opportunities and Constraints. Current issues in Tourism 5(3): 338-360.
Jhala Y., Qureshi Q. \& Gopal R., 2015, The status of tigers in India 2014. National Tiger Conservation Authority, New Delhi and Wildlife Institute of India, Dehradun.

Karanth K.K. \& Defries R., 2010, Nature-based tourism in Indian protected areas: New challenges for park management. Centre for Wildlife Studies 4(2): 137-149.

Naughton-Treves L., Holland M.B. \& Brandon K., 2005, The role of protected areas in conserving biodiversity and sustaining local livelihoods. Annual Review of Environment and Resources 30: 219-252.

Rodgers W., Hartley D. \& Bashir S., 2003, Community Approaches to Conservation: Some Comparisons from Africa and India, [in:] V. Saberwal, M. Rangarajan (eds.) Battle Over Nature: Science and the Politics of Conservation, Permanent Black, Delhi: 324-382.

Roy A., Vicky, \& Chaudhary P., n.d., Protected Areas of Central India and livelihood issues of nearby community. Field Forester 5(2): 237-242.

Satpura Tiger Reserve. (http://www.satpuratigerreserve. mp.gov.in/).

Spiteri A. \& Nepal S.K., 2008, Evaluating Local Benefits from Conservation in Nepal's Annapurna Conservation Area. Environmental Management 42(3): 231-401.

State of Forest Report, 2017, Forest Survey of India (FSI). Ministry of Environment, Forests and Climate Change, Dehradun, India.

Walpole M.J., Goodwin H.J. \& Ward K.G., 2001, Pricing Policy for Tourism in Protected Areas: Lessons from Komodo National Park. Conservation Biology 15: 218227. 